\title{
Analisis Komunikasi Pemasaran Go-Pay Melalui Promosi Cashback
}

\author{
Edwin Notowijoyo, Riris Loisa \\ edwin.915130049@stu.untar.ac.id,ririsl@fikom.untar.ac.id \\ Fakultas Ilmu Komunikasi Universitas Tarumanagara
}

\begin{abstract}
Promotion was a product of marketing communication, marketing activity which try to spreading an information, influence or persuade and reminding the targeting market so the product can be acceptable, bought, and loyal with the product. GO-PAY was one of a product of Fintech from GO-JEK, which is an innovation in a finance where money doesn't exist physicly but in a form of digital or electronic so the transaction could be easier. The purpose of this research was to know is cashback $20 \%$ was a strategy of marketing communication for GO-PAY or not. The research using the metode of qualitative descriptive with data collection technique from case study. The instrument was interview and documentation with sr.Merchant Acquisition Executive from Consument Relation team and Owner of Indio Koffie. The result from the research was cashback was a promotion which GO-JEK use for promoting GO-PAY by choosing the right media and involving the partners.
\end{abstract}

Keywords: cashback, promotion, marketing communication

\begin{abstract}
Abstrak
Promosi adalah suatu bentuk komunikasi pemasaran, sebuah aktivitas pemasaran yang berusaha menyebarkan informasi, mempengaruhi atau membujuk, dan mengingatkan pasar sasaran atas produknya agar diterima, dibeli, dan loyal pada produknya. GO-PAY adalah sebuah produk Fintech dari GO-JEK, yaitu sebuah inovasi di dalam bidang jasa keuangan yang di mana uang secara fisik dijadikan bentuk digital atau elektronik dengan tujuan untuk memudahkan kegiatan transaksi. Tujuan penelitian ini adalah untuk mengetahui apakah cashback $20 \%$ adalah strategi komunikasi pemasaran dalam memasarkan GO-PAY di dalam bentuk promosi. Pendekatan penelitian kualitatif deskriptif dengan metode studi kasus. Pengumpulan data dilakukan melalui wawancara dan dokumentasi dengan narasumber yaitu sr.Merchant Acquisition Executive di tim Consument Relation dan pemilik dari Indio Koffie. Berdasarkan hasil penelitian didapatkan bahwa program promosi cashback yang diterapkan oleh GO-JEK di dalam memasarkan GO-PAY dengan memilih media yang tepat dan mengikutsertakan mitra.
\end{abstract}

Kata Kunci: cashback, promosi, komunikasi pemasaran

\section{Pendahuluan}

Di era globalisasi ini di mana segala sesuatu dituntut untuk semakin praktis dan mudah, para produsen berusaha memenuhi segala tuntutan untuk menarik konsumen sebanyak-banyaknya. Namun permasalahan muncul tidak hanya terdapat pada masuknya konsumen baru, namun juga mempertahankan konsumen lama. Di dalam dunia komunikasi, promosi adalah salah satu cara untuk mempertahankan konsumen lama serta menarik konsumen baru. Untuk mempertahankan kerja sama antara produsen dan konsumen, produsen tidak pernah berhenti memberikan promosi untuk para konsumen-konsumennya, baik itu konsumen lama maupun konsumen baru. Karena bagi produsen jasa, kualitas pelayanan tidaklah cukup untuk memenuhi 
segala keinginan dan ekspektasi konsumen. Maka dari itu, perusahaan-perusahaan sekarang ini berlomba-lomba memberikan berbagai jenis promosi untuk menarik calon konsumen baru dan mempertahankan konsumen lama.

Pada hakikatnya promosi adalah suatu bentuk komunikasi pemasaran. Yang dimaksud komunikasi pemasaran adalah aktivitas pemasaran yang berusaha menyebarkan informasi, mempengaruhi atau membujuk, dan mengingatkan pasar sasaran atas produknya agar bersedia menerima, membeli dan loyal pada produknya (Tjiptono, 2010).

Jadi promosi sendiri adalah suatu bentuk kegiatan produsen yang diarahkan langsung kepada konsumen maupun calon konsumen agar terbentuk sebuah kegiatan transaksi serta membentuk loyalitas. Kegiatan promosi bias dalam bentuk apapun namun tujuan akhir dari serta sasaran dari kegiatan promosi tetaplah sama yaitu konsumen itu sendiri Promosi dapat menambah nilai suatu barang atau jasa dengan memberikan informasi kepada konsumen. Dapat berupa informasi baik tentang barangnya, harganya, keuntungannya, ataupun informasi lain yang memiliki kegunaan kepada konsumen. Tanpa adanya informasi seperti itu orang segan atau tidak akan mengetahui banyak tentang suatu barang, dengan demikian promosi merupakan suatu alat komunikasi bagi produsen untuk memberitahu kepada pihak lain tentang kebutuhan dan keinginan mereka, sehingga kebutuhan dan keinginan mereka dapat dipengaruhi dengan mengadakan pertukaran yang memuaskan. Selain bersifat memberitahu, promosi juga bersifat membujuk, menyadarkan, serta mempersuasi calon konsumen serta konsumen-konsumen potensial dengan segala bentuk promosi yang ditawarkan produsen. Selain itu promosi pun dapat membentuk kesan (image) tersendiri kepada konsumen serta calon konsumen untuk produk yang diiklankan. Karena pada akhirnya tujuan akhir dari promosi adalah menciptakan transaksi yang menguntungkan melalui komunikasi, sehingga keinginan konsumen dapat terpenuhi dan terpuaskan.

PT Aplikasi Karya Anak Bangsa atau yang lebih dikenal dengan GO-JEK merupakan sebuah perusahaan teknologi asal Indonesia yang melayani angkutan melalui jasa ojek. Perusahaan ini didirikan pada tahun 2010 di Jakarta oleh Nadiem Makarim. Saat ini GO-JEK telah tersedia di 50 kota di Indonesia, hingga bulan Juni 2016, Aplikasi GO-JEK sudah diunduh sebanyak hampir 10 juta kali di google play store pada sistem operasi android. Saat ini juga untuk di iOS, di App Store. GO-JEK juga menyediakan layanan pembayaran digital atau yang biasa kita sebut Fintech (Financial Technology) yaitu GO-PAY.

GO-PAY adalah sebuah produk Fintech dari GO-JEK. Fintech adalah sebuah inovasi di dalam bidang jasa keuangan yang di mana uang secara fisik dijadikan bentuk digital atau elektronik dengan tujuan untuk memudahkan kegiatan transaksi. Sebuah tuntutan di dalam era globalisasi ini dimana segala sesuatu dituntut untuk lebih mudah dan praktis. Dalam rangka memasarkan GO-PAY, GO-JEK bahkan memberikan sebuah promosi Cashback 20\% untuk setiap transaksi yang dilakukan menggunakan GO-PAY di toko-toko yang sudah bekerja sama dengan GO-PAY. Hal ini juga yang menjadi indikasi bagi peneliti, apakah kegiatan pemasaran GO-PAY melalui promosi cashback adalah komunikasi promosi yang benar dan tepat menurut ilmu komunikasi yang dapat menjadi pemicu bagi para calon konsumen yang belum menggunakan GO-PAY, serta memberikan efek loyalitas kepada konsumennya yang sudah menggunakan GO-PAY. 
Indio Kofie adalah salah satu toko yang bekerja sama dengan perusahaan GO-JEK, sehingga mendapatkan promosi cashback 20\% untuk para konsumennya, namun apakah promosi ini sudah tepat, dalam mengkomunikasikan konsumennya sehingga dapat memberikan efek puas bagi para konsumen yang sudah menggunakan GO-PAY, serta menarik konsumen-konsumen baru. Oleh karena itu, saya mengangkat topik "Analisis Strategi Komunikasi Pemasaran GO-JEK dalam Memasarkan GO-PAY”.

\section{Metode Penelitian}

Pada penelitian ini penulis menggunakan pendekatan penelitian kualitatif secara deskriptif Menurut Sugiyono (2014) metode penelitian kualitatif adalah metode penelitian yang berlandaskan pada filsafat postpositivisme, digunakan untuk meneliti pada kondisi objek alamiah, (sebagai lawannya adalah eksperimen) dimana peneliti adalah sebagai instrumen kunci, teknik pengumpulan data dilakukan secara gabungan, analisis data bersifat induktif/kualitatif, dan hasil penelitian kualitatif lebih menekankan makna daripada generalisasi nya. Jenis penelitian yang dipakai adalah penelitian deskriptif. Penelitian deskriptif menurut Kenneth D. Bailey adalah suatu penelitian yang bertujuan untuk memberikan gambaran tentang fenomena secara detail (Wibowo, 2013).

Denzin dan Lincoln (Moleong, 2009) menyatakan bahwa penelitian kualitatif adalah penelitian yang menggunakan latar alamiah, dengan maksud menafsirkan fenomena yang terjadi dan dilakukan dengan jalan melibatkan berbagai metode yang ada. Metode yang biasanya dimanfaatkan adalah wawancara, pengamatan dan pemanfaatan dokumen. Menurut Burhan Penelitian Kualitatif adalah penelitian yang memiliki tingkat kritisme yang lebih dalam semua proses penelitian. Kekuatan kritisme peneliti menjadi senjata utama menjalankan semua proses penelitian.

Penelitian deskriptif adalah studi untuk menemukan fakta dengan interpretasi yang tepat. Dalam desain deskriptif ini, termasuk desain untuk studi formulatif dan eksploratif yang berkehendak hanya untuk mengenal fenomena-fenomena untuk keperluan studi selanjutnya (Nazir, 2011). Studi deskriptif juga termasuk studi untuk melukiskan secara akurat sifat-sifat dari beberapa fenomena, kelompok atau individu dan Studi untuk menentukan frekuensi terjadinya suatu keadaan untuk meminimalisasikan bias dan memaksimumkan reliabilitas. Berdasarkan pengertian diatas, maka dapat disimpulkan bahwa metode deskriptif merupakan metode yang tepat bagi penulis yang di mana penelitian ini bertujuan untuk membahas dan menganalisis komunikasi pemasaran perusahaan GO-JEK di dalam memasarkan GO-PAY dengan menggunakan metode pengumpulan data melalui wawancara dan dokumentasi.

\section{Hasil Temuan dan Diskusi}

\section{Penggunaan Media}

Di dalam bukunya, Teori Komunikasi Massa Denis mcQuail (2011) ia menamakan media baru sebagai media telematic yang merupakan perangkat teknologi elektronik berbeda dengan penggunaan media yang berbeda pula, sementara itu, Martin Lister dkk dalam bukunya New Media : A Critical Introduction (2009) menyatakan bahwa terminology media baru mengacu pada perubahan skala 
besar dalam produksi media, distribusi media dan penggunaan media yang bersifat teknologis, tekstual, konvensional dan budaya.

Di dalam buku Denis McQuail menjelaskan bahwa media telematic atau media baru memiliki beberapa ciri utama, salah satunya adalah komunikasi timbal balik (interaktivitas): penerima dapat memilih, menukar informasi, menjawab kembali, dan dihubungkan dengan penerima lainnya secara langsung, sementara itu, Martin Lister dkk (2009) menyatakan bahwa media baru memiliki beberapa karakteristik yang salah satunya adalah hiperteks : teks yang mampu menghubungkan dengan teks lainnya di luar teks yang ada. Dari teori diatas penulis menemukan sebuah temuan berdasarkan data dari wawancara yang dilakukan dengan narasumber terkait (Stelly Maries) di dalam pernyataannya yang mengungkapkan bahwa media dapat menjadi sarana di dalam memberikan informasi, jaringan distribusi informasi, sarana promosi, serta sarana di dalam membangun brand awareness.

Di dalam pemilihan media, dari wawancara penulis menemukan bahwa media yang digunakan sebagai sarana yang dipilih oleh narasumber dibagi menjadi dua, yaitu media teknologi dan media konvensional. Media teknologi yang digunakan adalah, Instagram, whatsapp, facebook, twitter, dan media konvensional yang digunakan adalah banner dan poster. Di dalam wawancara, narasumber juga mengungkapkan bahwa pemilihan media dapat menjadi sebuah sarana di dalam membangun brand awareness bahkan menentukan pangsa pasar karena pemilihan serta penggunaan media yang baik adalah awal komunikasi yang baik.

Bagaimana caranya menentukan media yang tepat dan bagaimana menggunakannya? Narasumber mengungkapkan bahwa di dalam menentukan media apa yang paling tepat, GO-JEK melakukan sebuah riset untuk mendapatkan data-data yang diperlukan untuk menemukan jawaban media apa yang paling tepat untuk digunakan. Di dalam pemilihan media, pangsa pasar yang dituju juga menentukan, karena setiap media memiliki karakteristik yang berbeda sehingga penerapan di dalam menggunakannya pun juga berbeda. Seorang praktisi komunikasi yang baik tentu dapat menentukan media apa yang paling tepat yang akan digunakan untuk memenuhi berbagai tujuan komunikasi seperti membentuk citra, membangun brand awareness, pengiriman informasi, dan seterusnya.

\section{Menggunakan Data Riset Untuk Menentukan Strategi}

Menurut Hopkins WG (2002) riset adalah proses mengirimkan sebuah isu atau pertanyaan serta menjawab sebuah pertanyaan guna memecahkan masalah. Sehingga bias disimpulkan bahwa riset adalah sebuah cara untuk menemukan sebuah jawaban atau solusi dari sebuah permasalahan melalui pertanyaan yang diberikan kepada publik yang terkait.

Dari hasil wawancara terhadap narasumber terkait (Stelly Maries) penulis menemukan bahwa setiap keputusan yang diambil oleh pihak GO-JEK selalu berdasarkan hasil riset. Dari data riset yang didapatkan oleh pihak GO-JEK barulah sebuah keputusan akan sebuah kebijakan ataupun program ditentukan. Sebuah riset menjadi penting ketika kita dihadapkan oleh keputusan yang mempengaruhi masa atau publik yang belum kita ketahui minatnya, karena dari data riset kita juga dapat menentukan tentang jenis komunikasi yang terbaik untuk mempersuasi massa atau publik. Selain itu, data riset juga dapat menjadi jawaban untuk permasalahan yang sudah terjadi, contohnya seperti memperbaiki citra perusahaan atau image brand yang sudah rusak dengan melakukan riset terhadap masa atau publik terkait, selain 
itu tidak menutup kemungkinan data riset dapat menghasilkan kemungkinan baru dalam penerapan, membuka jalan baru untuk sebuah masalah, atau malah menemukan masalah baru.

\section{Promosi dalam Bentuk Informasi}

Menurut Romney dan Steinbart (2009) mendefinisikan arti informasi sebagai data yang telah diproses dan diorganisasikan, sehingga dapat memberikan arti atau manfaat bagi orang yang menggunakannya. sehingga dapat disimpulkan bahwa informasi dapat diolah sedemikian rupa untuk kepentingan pemberi informasi. bahkan bisa dikatakan sebuah informasi dapat dimanipulasi.

Sebuah informasi yang disebarkan dapat memiliki tujuan tertentu didalamnya, informasi juga dapat dijadikan sebuah alat untuk kegiatan seperti promosi. tentu sebuah kegiatan promosi akan selalu memuat informasi di dalamnya, namun, bila diolah dengan baik, sebuah informasi dapat menjadi sebuah kegiatan promosi.

Di dalam hasil wawancara penulis dengan narasumber (Dio), penulis menemukan adanya informasi yang disebarkan ataupun diinformasikan kepada setiap pengunjung di kedai kopi milik narasumber yang memiliki tujuan promosi didalamnya. berkaitan dengan teori dari Tjiptono (2010) tentang komunikasi pemasaran sebagai aktivitas pemasaran yang berusaha menyebarkan informasi, begitu pula dengan kegiatan promosi dengan memberikan informasi yang telah diolah untuk tujuan promosi.

\section{Komunikasi Pemasaran yang Baik}

Komunikasi pemasaran adalah suatu proses sosial dan manajerial yang didalamnya individu dan kelompok mendapatkan apa yang mereka butuhkan dan inginkan dengan menawarkan produk yang bernilai kepada pihak lain, di dalam kasus ini biasanya yang diinginkan oleh komunikator atau perusahaan yang melakukan komunikasi pemasaran adalah uang dengan menawarkan produk yang mereka produksi sebagai penawarannya. Namun di dalam kasus GO-JEK ini, GOJEK menawarkan cashback untuk produk merchant yang bekerja sama dengan GOJEK untuk transaksi pembayaran dengan menggunakan GO-PAY.

Di dalam kasus GO-PAY, GO-JEK menentukan promosi sebagai strategi komunikasi pemasaran yang paling tepat untuk memasarkan GO-PAY, namun di dalam menjalankan strategi tersebut, tahapan-tahapan atau urutan di dalam melakukan eksekusi strategi komunikasi pemasaran juga sangatlah penting. Mengetahui posisi brand kita di dalam masyarakat, kekuatan dan kekurangan produk, serta target pasar yang ingin diraih, hal-hal tersebut dapat diketahui melalui riset yang sudah dibahas di atas. Jawaban dari riset tersebutlah yang dapat dijadikan acuan di dalam menentukan tahapan eksekusi komunikasi pemasaran yang akan dilaksanakan.

Berdasarkan hasil wawancara dari segi merchant yang bekerja sama, peneliti menemukan bahwa penyebaran informasi sebagai tahap awal di dalam komunikasi pemasaran, penyebaran informasi di dalam bentuk apapun, sangatlah membantu di dalam proses eksekusi komunikasi pemasaran. Penyebaran informasi dapat membantu perusahaan untuk mempersuasi public dengan informasi yang mereka ingin sebarkan kepada masyarakat, system penyebaran informasi yang baik dapat membentuk persepsi masyarakat yang dapat dibentuk searah dengan yang diinginkan 
oleh perusahaan. Di dalam komunikasi pemasaran, mempersuasi public dan membentuk persepsi sangatlah penting

Berdasarkan data yang didapat oleh peneliti berdasarkan wawancara, peneliti menemukan bahwa penyebaran informasi sebagai bentuk komunikasi pemasaran harus dikemas dengan sedemikian rupa sehingga dapat memberikan efek persuasif, karena persepsi masyarakat yang terbentuk nantinya akan sangat berpengaruh dengan tahapan selanjutnya di dalam menentukan komunikasi pemasaran apa yang akan dilakukan. Namun hasil yang diinginkan dari komunikasi pemasaran tidak hanya membentuk persepsi masyarakat namun juga mempertahankan persepsi baik yang sudah terbentuk.

Komunikasi pemasaran yang baik tidak hanya membentuk persepsi yang baik di tengah masyarakat terhadap produk, namun juga mempertahankannya. Dengan kata lain, komunikasi pemasaran yang baik dapat menciptakan pelanggan-pelanggan yang loyal. Berdasarkan kutipan di atas penulis menemukan bahwa hasil dari komunikasi pemasaran yang baik selain membentuk persepsi yang baik, namun juga menciptakan pelanggan-pelanggan yang loyal dengan brand. Di dalam menentukan komunikasi pemasaran, segmentasi pasar yang sudah dibahas di atas juga sangat penting untuk dipertimbangkan, namun berbeda dengan brand lainnya, pangsa pasar atau segmentasi pasar yang ingin diraih oleh GO-JEK sangatlah luas.

\section{Cashback sebagai bentuk promosi}

Promosi pada hakekatnya adalah suatu komunikasi pemasaran, artinya aktivitas pemasaran yang berusaha menyebarkan informasi, mempengaruhi/membujuk, dan atau mengingatkan pasar sasaran atas perusahaan dan produknya agar bersedia menerima, membeli dan loyal pada produk yang ditawarkan perusahaan yang bersangkutan, Tjiptono (2001). Sementara Sistaningrum (2002) mengungkapkan arti promosi adalah suatu upaya atau kegiatan perusahaan dalam mempengaruhi "konsumen aktual" maupun "konsumen potensial" agar mereka mau melakukan pembelian terhadap produk yang ditawarkan, saat ini atau dimasa yang akan datang. Konsumen aktual adalah konsumen yang langsung membeli produk yang ditawarkan pada saat atau sesaat setelah promosi produk tersebut dilancarkan perusahaan. Dan konsumen potensial adalah konsumen yang berminat melakukan pembelian terhadap produk yang ditawarkan perusahaan dimasa yang akan datang.

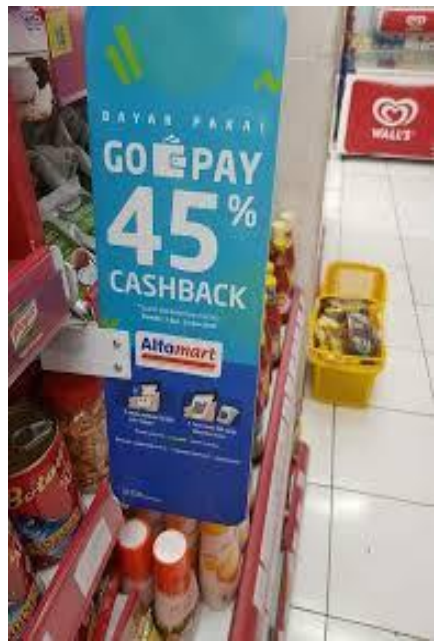

Gambar 3.1 Banner Cashback

Sumber: Dokumentasi Peneliti (2019) 
Dari teori di atas penulis menemukan bahwa kemampuan promosi untuk membawa konsumen kembali melakukan kegiatan transaksi sangatlah tinggi, meskipun promosi sangat dekat hubungannya dengan brand awareness, namun tujuan utamanya tidak hanya itu, promosi tidak hanya untuk mengingatkan pasar sasaran suatu produk atau merek dari perusahaan, namun juga mempersuasi pasar sasaran, selain itu promosi juga dapat menjadi sebuah media di dalam menyebarkan informasi.

Cashback sebagai bentuk promosi dari GO-JEK di dalam mempromosikan GO-PAY juga menjadi sebuah senjata komunikasi dari GO-JEK yang berusaha mempersuasi seluruh segmentasi pasar yang ingin diraih GO-JEK sebagaimana sudah dibahas di atas mengenai segmentasi pasar GO-JEK. Eksekusi cashback sebagai strategi komunikasi juga didukung oleh penggunaan-penggunaan media tidak hanya media elektronik, namun juga media digital.

\section{Simpulan}

Promosi sebagai penerapan dari komunikasi pemasaran menghasilkan hasil yang sangat baik dalam memasarkan GO-PAY. Selain daripada memasarkan GOPAY, promo cashback ini juga memberikan dampak yang tidak sedikit kepada Indio Koffie sebagai salah satu toko yang bekerja sama dengan GO-JEK. dari penelitian ini dapat disimpulkan juga bahwa di dalam memasarkan sesuatu, ketika brand sudah dikenali banyak khalayak, promosi menjadi salah satu cara mempertahankan loyalitas dari pelanggan. Selain itu peneliti mendapatkan banyak pelajaran tentang menerapkan sistem promosi yang baik, karena di dalam pengaplikasiannya, membuat promosi yang baik tidak semudah itu dilakukan. Banyak faktor-faktor yang tidak hanya mendukung namun juga bisa berbalik menyulitkan. Peneliti juga menemukan bahwa kegiatan promosi yang baik memiliki tahapan-tahapan dalam pengaplikasiannya.

\section{Ucapan Terima Kasih}

Ucapan terima kasih penulis ucapkan kepada Stelly Maries dan Dio Octa Christie yang telah bersedia menjadi informan dalam penelitian ini. Peneliti juga mengucapkan terima kasih pada seluruh pihak yang telah membantu dan mendukung peneliti dalam proses penyusunan skripsi.

\section{Daftar Pustaka}

Tjiptono, Fandy (2015). Strategi Pemasaran (ed. 4). Jakarta: Andi Publisher Moleong, J Lexy. (2009). Metode Penelitian Kualitatif. Bandung: PT Remaja Rosdakarya 